\title{
Encruzilhadas museológicas: ressonâncias da presença/ausência de Exu no Museu Afro-Brasileiro de Sergipe
}

Museological crossroads: resonances of the presence/absence of Exu in the AfroBrazilian Museum of Sergipe

http://dx.doi.org/10.1590/1982-02672019v27e20

CLOVIS CARVALHO BRITTO'

https: / / orcid.org/0000-000 1-6267-544X

Universidade de Brasília / Brasília, DF, Brasil

\section{FERNANDO JOSÉ FERREIRA AGUIAR²}

https:/ / orcid.org/0000-0003-4052-1495

Universidade Federal de Sergipe / Laranjeiras, SE, Brasil

\author{
JANAINA COUVO TEIXEIRA MAIA DE AGUIAR ${ }^{3}$ \\ https: / / orcid.org/0000-0001-9392-8534 \\ Universidade Federal de Sergipe / Laranjeiras, SE, Brasil
}

RESUMO: $O$ artigo analisa algumas configurações no campo da Antropologia dos Museus, tendo como estudo de caso os usos e as apropriações dos acervos afrorreligiosos existentes no Museu Afro-Brasileiro de Sergipe, em Laranjeiras, SE. A partir de narrativas sobre o contexto da criação do museu, dos dados sobre a formação da Sala de Exu e da análise dos conflitos em torno da representação e da musealização de elementos que evocam a presença e a ausência do orixá Exu na exposição museológica, demonstra múltiplas estratégias da produção de "sagrados" em contextos e instituições seculares. Do mesmo modo, evidencia as ressonâncias presentes nos deslocamentos de bens afrorreligiosos e os conflitos em torno das políticas de (auto) representação materializadas em ações de musealização e de patrimonialização das diferenças culturais.

PALAVRAS-CHAVE: Antropologia. Museus Afro. Acervo afrorreligioso. Exu.

\begin{abstract}
1. Professor na Faculdade de Ciência da Informação da Universidade de Brasília (UnB) e no Programa de Pós-Graduação em Museologia da Universidade Federal da Bahia. Doutor em Sociologia pela UnB. E-mail: <clovisbritto@unb. br>

2. Professor adjunto e vicechefe do Departamento de Museologia da Universidade Federal de Sergipe (UFS), professor permanente do Programa de Pós-Graduação em Arqueologia (PROARQ/ UFS) e do Programa Interdisciplinar em Culturas Populares (PPGCULT/UFS). Doutor em Educação pelo Programa de Pós-Graduação em Educação pela mesma universidade. E-mail: $<$ fernandofaguiar36@yahoo. com.br>

3. Professora de História e Arte da Secretaria Estadual de Educação de Sergipe e Professora Substituta do Curso de Museologia da UFS. Doutoranda em Museologia pela Universidade Lusófona de Humanidades e Tecnologias (ULHT). E-mail: $<$ janainacouvo@gmail.com>
\end{abstract}


ABSTRACT: The article analyzes some configurations in the field of Anthropology of Museums having as a case study the uses and appropriations of the afro-religious collections existing in the Afro-Brazilian Museum of Sergipe, in Laranjeiras-SE. Based on narratives about the context of the creation of the museum, data about the formation of the Exu Room and the analysis of the conflicts around the representation and musealization of elements that evoke Exu in the museological exhibition demonstrates multiple strategies of the production of "sacred" in secular contexts and institutions. In the same way, it highlights the resonances present in the movements of afro-religious goods and the conflicts around the (self) representation policies materialized in musealization actions and patrimonialization of cultural differences.

KEYWORDS: Anthropology. Afro Museums. Afro-religious collection. Exu. 
Presente artigo analisa as transformações da representação do orixá Exu no Museu Afro-Brasileiro de Sergipe (Mabs), em Laranjeiras, SE, tendo como estudo de caso os usos e as apropriações em torno da musealização dos acervos afrorreligiosos naquela instituição. Resulta, desse modo, de "experiências etnográficas" realizadas por três agentes que ao longo dos anos e de modo variado têm efetuado e orientado pesquisas sobre as intersecções entre o campo dos museus, da Antropologia e das religiões afro-brasileiras. Aqui sublinha esse conceito a partir do entendimento de José Guilherme Cantor Magnani quando diferenciou a "prática etnográfica" da "experiência etnográfica", destacando que "enquanto a prática é programada, contínua, a experiência é descontínua, imprevista. No entanto, esta induz àquela, e uma depende da outra" ${ }^{4}$

Exu é uma divindade africana relacionada à comunicação e é presença fundamental nos rituais das religiões afro-brasileiras. Na umbanda, devido às várias reinterpretações ocorridas em virtude das influências religiosas do catolicismo e do espiritismo, possui significações que remetem tanto à visão etnocêntrica cristã, considerando-o enquanto uma representação do anjo caído, quanto a uma entidade em evolução, fruto do olhar espírita sobre a divindade. No candomblé, Exu está presente dentro da sua concepção africana, enquanto uma divindade responsável pela comunicação, o mensageiro que recebe as primeiras oferendas para que as relações entre os indivíduos e as demais divindades possam ser construídas.

É importante compreender o modo como estes significados foram construídos em torno dessa divindade. $\bigcirc$ culto a Exu desenvolvido pelos povos iorubas, ${ }^{5}$ por exemplo, foi apresentado aos viajantes europeus assim que estes chegaram à África:

Os escritos de viajantes, missionários e outros observadores que estiveram em território fon ou iorubá entre os séculos XVIII e XIX, todos eles de cultura cristã, quando não cristãos de profissão, descreveram Exu sempre ressaltando aqueles aspectos que o mostravam aos olhos ocidentais, como entidade destacadamente sexualizada e demoníaca. ${ }^{\circ}$

As representações ritualísticas africanas sobre Exu, destacando suas formas fálicas e as narrativas sobre suas aventuras, contribuíram para que os viajantes religiosos relacionassem a divindade ao demônio, aspecto que foi sendo repassado pelos diversos escritos, principalmente os que registravam as histórias do continente africano e seus costumes.

É importante ressaltar que no Brasil Exu possui várias "faces" que, segundo Vagner Gonçalves da Silva, ${ }^{7}$ são resultantes de todo o processo de imposição cristã
4. Magnani (2009, p. 136).

5. Para os iorubas, Exu é o princípio primordial, elo de comunicação entre o mundo dos deuses e o mundo dos homens. Divindade de origem iorubana, na diáspora atlântica negra, em razão dos contatos entre povos de origens étnicas distintas, passou a ter correlações com outras divindades estrangeiras (oriundas de outros povos africanos da parte ocidental atlântica), fora justaposta ou até mesmo sincretizada com essas outras divindades que possuíam similitudes no que diz respeito a arquétipos, função religiosa e uso de interseção. Antes mesmo da diáspora negra atlântica, cabe destacar as relações de contatos, negociações e conflitos entre povos vizinhos a exemplo das populações e, em muitos casos, as dinâmicas dos cultos familiares e locais que passam a dialogar entre grupos diferentes, p os s i b i 1 i a $\mathrm{nd}$ o incorporações ou exclusões de cultos a divindades cultuadas por outros povos. Na diáspora negra atlântica e na elaboração do candomblé na experiência brasileira, várias divindades, cujos cultos se perderam sendo incorporadas ao culto a outros orixás, sob a forma de "qualidades" ou "caminhos".

6. Prandi (2001, p. 47).

7. Cf. Silva (2013). 
aos africanos escravizados submetidos às devoções religiosas controladas pela igreja. Essas faces teriam contribuído para uma leitura ambígua em torno de sua figura, resultando em uma divindade ordeira e mensageira que, paradoxalmente, também promoveria o caos social.

Essas concepções diferenciadas de Exu se refletem em suas representações, evidenciadas, por exemplo, na cultura material presente nos terreiros de candomblé e umbanda que representa essa divindade/entidade ora com a presença de chifres, ora apenas nos assentamentos com elementos em forma de tridente. Essas representações contribuem para a manutenção de uma visão deturpada da divindade, pois Exu, na realidade, está ligado ao movimento, e é aquele que permite o contato com o mundo sagrado das divindades, que mantém o equilíbrio dos rituais, sendo fundamental para os ritos das religiões afro-brasileiras.

Nas narrativas mitológicas sobre Exu, é possível encontrar dois aspectos importantes: o seu caráter ambíguo e a sua prioridade no recebimento das oferendas. Torna-se necessário destacar que os mitos são reafirmados por meio de uma presença constante da oralidade dentro das casas de culto, o que é o caminho para o aprendizado, para a troca de conhecimentos entre o povo de axé. Com isso, as grandes aventuras dos orixás são interpretadas, analisadas e retiradas dessas narrativas que contêm as orientações necessárias para cuidar e se relacionar com cada divindade.

Um estudo importante sobre a mitologia dos orixás foi desenvolvido por Reginaldo Prandi, ${ }^{8}$ que apresenta um número extraordinário de orikis e a descrição de suas oferendas e dos comportamentos. Eleguá, Elegbara, Legbá, Exu, são nomes próprios atribuídos a uma mesma deidade, considerando suas próprias interfaces na manutenção dos cultos:

Olofim estava muito doente. Muitos foram vê-lo, mas não se encontrou o que o curasse. Por esses tempos, Eleguá comia o que o lixo lhe dava, convivendo com a miséria. Sabendo da doença de Olofim, Eleguá vestiu um gorro branco, igual aos que usam os babalaôs, e foi visitar o velho rei. Levou consigo suas ervas e com seu poder curou Olofim. Olofim ficou agradecido. Perguntou a Eleguá qual deveria ser a recompensa. Eleguá, que conhecia o que era a miséria, Eleguá, que provara do desprezo de todos, pediu-the que the dessem primazia nas oferendas, que the dessem sempre um pouco de tudo o que dessem a qualquer um. E que o pusessem à entrada da casa. E para que fosse saudado pelos que saíssem à rua. Olofim estava grato a Eleguá. Olofim deu tudo o que Eleguá pediu. ${ }^{9}$

Exu tem prioridade nos rituais do candomblé. É a divindade que primeiro deve receber as oferendas. Suas comidas, à base de farinha de mandioca, dendê, 
cachaça e pimenta, são preparadas com todo o cuidado, para que possa receber tudo corretamente. E esse cuidado com as oferendas é muito presente nos terreiros de candomblé, pois acredita-se que qualquer ação preparada erroneamente pode resultar em problemas no desenvolvimento dos rituais e na vida de seus adeptos.

É em busca do equilíbrio das atividades religiosas de um terreiro que os agentes afirmam que se deve ter cuidado extremo com os rituais dedicados a Exu. Seja em rituais internos, seja em públicos, a busca do sucesso na realização dos rituais é constante, conferindo a Exu o poder de manter a ordem ou a desordem no espaço religioso. Essa ambiguidade que marca a entidade, de instituir a ordem a partir do caos, evoca as análises de Mary Douglas:

\begin{abstract}
Admitindo-se que a desordem estraga o padrão, ela também fornece os materiais do padrão. A ordem implica restrição; de todos os materiais possíveis, uma limitada seleção foi feita e de todas as possíveis relações foi usado um conjunto limitado. Assim, a desordem por implicação é ilimitada, nenhum padrão é realizado nela, mas é indefinido seu potencial para a padronização. Daí o porquê, embora procuremos criar a ordem, nós simplesmente não condenamos a desordem. Reconhecemos que ela é nociva para os modelos existentes, como também que tem potencialidade. Simboliza tanto o perigo quanto poder. ${ }^{10}$
\end{abstract}

É por essa razão que a relação de poder atribuída a Exu ultrapassa o espaço religioso, acompanhando o cotidiano dos iniciados, já que Exu é movimento, está intimamente relacionado à dinamicidade característica das religiões afro-brasileiras e do próprio espaço de domínio dessa divindade, ou seja, a rua, as encruzilhadas, os lugares de trânsito e passagem. Pensar em Exu é pensar no movimento, na multiplicidade, na dinâmica do axé. Sendo assim, o equilíbrio e o desequilíbrio, a ordem e a desordem são elementos que essa divindade domina e que, por isso, é tão respeitada e temida.

Ao longo da pesquisa, registramos aspectos da cultura material e do patrimônio afrorreligioso em Sergipe. Neste texto, analisamos as tensões em torno da presença/ausência de Exu no Museu Afro-Brasileiro de Sergipe (Mabs), caso exemplar para evidenciarmos as transformações no campo da Antropologia dos museus, especialmente em espaços que evidenciam a temática afrorreligiosa, a exemplo da constituição de um dos primeiros museus com a temática explicitamente afro-brasileira. Todavia, antes de visualizarmos esses itinerários em Sergipe, é importante evidenciar algumas implicações da presença de objetos religiosos afro-brasileiros em acervos de museus e as ressonâncias advindas dos processos de musealização. 
11. Brulon (2018, p. 91).

12. Cf. Herbele (2015).

13. Cunha (2006, p. 2)

\section{ITINERÁRIOS DA MUSEALIZAÇÃO DE OBJETOS AFRORRELIGIOSOS}

A musealização consiste em um conjunto de procedimentos marcados pelo deslocamento simbólico dos objetos, tornando aquilo que Bruno Brulon reconheceu como uma passagem criadora que promove novas realidades, "ato social de construção de valores e transformação de realidades por meio da comunicação museológica, como o seu principal objeto de investigação"." Segundo essa interpretação, a musealização instauraria um novo estado para os objetos, revestindo-os de uma sacralidade.

Essa situação adquire contornos específicos no caso da musealização de objetos religiosos, cuja passagem criadora instauraria um "duplo sagrado" ou uma metassacralidade. Além disso, é importante reconhecer os múltiplos deslocamentos entre a imagem de origem religiosa e o espaço público por meio do processo de musealização, gerando aquilo que Fernanda Herbele apresenta como um paradoxo marcado pela convivência entre o sagrado religioso e o sagrado encarnado no patrimônio público traduzido pela instituição museal. ${ }^{12}$

No caso brasileiro, essas tramas podem ser evidenciadas nas ações de preservação de objetos representativos das culturas negras, espaço poético e político na produção e seleção de narrativas sobre a nação. Nesse aspecto, como ato criativo, a musealização pode contribuir para a monumentalização ou para o silenciamento de discursos, transformando-se em um exercício de poder, conforme sublinhou Marcelo Bernardo Cunha em seu estudo sobre as culturas africanas e das diásporas negras em exposições museológicas:

Exercício de preservação e patrimonialização estão relacionados à explicitação de elementos constituintes das culturas e ao modo como matrizes culturais são historicamente construídas, sistematizadas e selecionadas, bem como formas pelas quais cada sociedade pretende representar-se e identificar-se em processos nos quais abordagens e programas de preservação sequem caminhos que, na maioria das vezes, reafirmam e reproduzem preconceitos em outras bases. Tendo o Brasil, em sua história, elites ávidas por branqueamento e construção de auto-imagens atravessadas pela presença de europeus, seus modos de vida e crenças, como lugares comuns em discursos marcados por visões eurocêntricas na formulação de uma pretensa "cultura nacional", tendem para deslocamentos e discriminações no que tange ao tratamento patrimonial de "culturas negras" ou "culturas de negros" [...] Os processos de patrimonialização, na perspectiva da identificação, registro e mesmo apropriação de elementos da cultura material por acervos e coleções oficialmente instituídos, não implicam a preservação dessas culturas em si, mas podem e devem contribuir para reflexões sobre dimensões sociais de tal produção. ${ }^{13}$ 
Essa reflexão contribui para compreendermos os gestos de resistência e de produção de sentidos construídos pela musealização enquanto ação criadora. No caso das culturas negras, consiste em um gesto de fabricação e arquivamento de narrativas que podem problematizar ou reforçar o discurso canônico da nação.

É emblemático que um dos primeiros patrimônios tombados pelo então Serviço do Patrimônio Artístico e Nacional consiste na Coleção Museu de Magia Negra do Museu da Polícia Civil do Rio de Janeiro, em 1938. Os objetos afrorreligiosos apreendidos pela polícia no início do século XX consistem no primeiro tombamento etnográfico do país e sua trajetória foi silenciada durante décadas na história do patrimônio brasileiro, tendo sido relegados à marginalidade. $\mathrm{Na}$ verdade, os deslocamentos dos objetos afrorreligiosos para a "coleção-museu" resultaram em um silenciamento, oriundo inicialmente do contexto de fins do século XIX e início do XX que reconhecia esses objetos como expressões da inferioridade racial e testemunhos materiais do exercício daquilo que se convencionou designar de magia negra (tipificada como charlatanismo, baixo espiritismo e sortilégios). ${ }^{14}$

Esse movimento demarca um conjunto de coleções de origem afrorreligiosa no Brasil no início do século XX, oriundo da repressão policial e atravessado por múltiplos deslocamentos: objetos religiosos, provas de crime, evidência científica, expressão artística e objeto museológico. Desses deslocamentos originaram, por exemplo, a coleção afrorreligiosa do extinto Museu Estácio de Lima, em Salvador, BA; do Museu Galdino Bicho, do Instituto Histórico e Geográfico de Sergipe, em Aracaju, SE; e a coleção Perseverança, do Instituto Histórico e Geográfico de Alagoas, em Maceió, AL.

Essas transformações na representação dos objetos afrorreligiosos foram analisadas por Roger Sansi-Roca ${ }^{15}$ em seu estudo sobre as mudanças no valor museográfico do candomblé na cidade de Salvador, na Bahia, ao longo do século $X X$, investigando de coleções policiais a memorais de terreiros ou de objetos de fetichismo a patrimônio cultural. $\bigcirc$ pesquisador iniciou sua análise sobre a coleção do Instituto Geográfico e Histórico da Bahia, fruto de apreensões policiais:

São as armas místicas da feitiçaria, e não as provas da falsa medicina, o que eles procuram. Essas armas são atabaques, contas e otás (pedras) - elementos sem dúvida centrais no candomblé, mas que dificilmente seriam identificados como "armas" por pessoas que não estivessem familiarizadas com o culto. Isso é normal, dado que os policiais vinham das mesmas camadas sociais que os praticantes de candomblé: alguns inclusive eram iniciados [...] $\bigcirc$ resultado, paradoxal, é que, perseguindo as práticas da feitiçaria, os policiais reconhecem o seu valor; não o negam - não vêem a feitiçaria como uma forma de falsa cons-
14. Cf. Corrêa (2006).

15. Cf. Sansi-Roca (2007). 
16. Ibid., p. 99).

17. Cf. Sansi-Roca (2007).

18. Cf. Sandes (2010). ciência, mas como uma técnica efetiva (Maggie, 1992). Nesse sentido, a luta pelo "progresso" e a "modernidade" continha notáveis ambiguidades. ${ }^{16}$

As análises de Roger Sansi-Roca contemplam as transformações dos significados atribuídos a essas coleç̃̃es ao longo do século XX em Salvador. Por décadas apresentados nos museus como provas de crime e/ou documentos da degenerescência respaldados nos discursos da Antropologia Criminal, conforme difundido pelas narrativas do Museu Estácio de Lima, os discursos oriundos da musealização foram ressignificados. Exemplo contundente apresentado pelo autor consiste no manifesto de intelectuais ligados às casas de candomblé integrantes da Sociedade de Proteção e Defesa dos Cultos Afro-Brasileiros que denunciou o Museu Estácio de Lima em 1996 por atentado à moral pública: problematizaram a representação dos objetos como exemplares patológicos e criminológicos, deslocando as narrativas museológicas para uma leitura de arte sacra negra.

Segundo o pesquisador, é emblemática nesse deslocamento a criação do Museu Afro-Brasileiro de Salvador, projetado no início dos anos de 1970 no Centro de Estudos Afro-Orientais da Universidade Federal da Bahia, com a participação central do fotógrafo e etnólogo Pierre Verger, responsável pela compra de objetos no Benim, em 1975, mas somente inaugurado em 1982.17 Especificamente sobre a cultura material religiosa afro-brasileira no Museu AfroBrasileiro da Bahia, Juipurema Sarraf Sandes ${ }^{18}$ elencou quatro macroclasses a partir do inventário do acervo e de estudos preliminares da documentação: insígnia, instrumento sonoro, utensílio e vestuário. De acordo com suas análises, muitos artefatos de origem africana também foram adquiridos por meio de doação do Ministério das Relações Exteriores, de pesquisadores e das embaixadas da República Democrática do Congo, República de Angola, República Federal da Nigéria, República do Senegal, além das cópias em gesso enviadas pelo Museu Real de África Central, em Tervuren, Bélgica.

Na verdade, o acervo do Museu Afro-Brasileiro de Salvador não é composto apenas de objetos afrorreligiosos e suas coleções não foram resultado exclusivo de compra ou doação das embaixadas e pesquisadores. Muitos objetos foram fruto de doações de mães e pais de santo da Bahia, cuja musealização resultou na "sacralização" de artefatos sacralizados ou envoltos pela aura da sacralidade. Nesses termos, os novos olhares lançados por meio da musealização contribuíram para múltiplos deslocamentos sobre o acervo, o que implicou e implica um conjunto de ações para combater visões preconceituosas e estereotipadas sobre os legados das culturas negras. 
Uma dessas experiências consistiu na exposição de curta duração intitulada Exu: outras faces, realizada no Museu Afro-Brasileiro de Salvador em 2013, cujo objetivo foi evitar "conceitos cristalizados sobre o orixá iluminando outras faces, buscando surpreender o público com a sua polissemia e mesmo a reconhecer-se em uma ou nas múltiplas faces do orixá" ${ }^{19}$ A exposição consistiu em uma tentativa de desconstruir leituras que demonizam o orixá, as religiões afro-brasileiras e a cultura material dela originária ou representativa, seguindo, para tanto, uma organização temática que destacava corpo, línguas, artes, escrita, tecnologia, caminhos e continuidade:

Por mais que os elementos fálicos, rabos, tridentes e chifres aparecessem nas peças, elas deveriam dialogar com outros elementos da exposição, pois era preciso apresentar outras dimensões, por esse motivo a equipe de curadoria optou por uma estratégia complexa de deslocamento das representações já consolidadas no imaginário social. A estratégia consistia em fazer com que os objetos expostos pudessem dialogar através de linguagens que provocassem novas identificações, como no caso dos espaços com espelhos. Este lugar fronteiriço entre o explícito e o implícito, determinou a estratégia de não expor o conjunto de cinco ogós africanos, bastões fálicos de Exu, do acervo do museu, tendo em vista que uma das marcas mais evidentes e difundidas do orixá é a sua relação com a sexualidade, portanto o fato de evitar a sua exibição não se deu por negação, tabu ou censura, mas para permitir o destaque de outras características, a partir de elementos expostos ou silenciados, num processo de negociação e intervenção. ${ }^{20}$

Essas transformações acionadas pelo processo de musealização dos acervos afrorreligiosos também podem ser evidenciadas no Museu Afro-Brasil, inaugurado em outubro de 2004, em São Paulo, a partir da coleção do artista Emanoel Araújo. $\bigcirc$ museu construiu uma narrativa sobre as memórias afro-brasileiras que reconhece os discursos e as perspectivas dos negros e negras enquanto protagonistas na escrita da cultura brasileira. Especificamente sobre o acervo afrorreligioso, Maria Aparecida de Oliveira Lopes destaca que o museu apresenta um núcleo sobre arte religiosa que evidencia objetos litúrgicos, com altares, pejis dos candomblés e congás da umbanda, esculturas de orixás, ferramentas de ferro forjado e vestimentas litúrgicas, com destaque para a figura de Exu:

A imagem dos orixás apresentando-se nas festas públicas no barracão de terreiros, com suas insígnias, roupa, danças e músicas, foram divulgadas nos trabalhos dos artistas Pierre Verger e Caribé. Além dos artistas, pintores e fotógrafos que tratam desta abordagem, o museu apresenta manequins vestidos de orixás, atabaques, estátuas, os assentamentos e altares. $\bigcirc$ assentamento de Exu é o mais polêmico entre eles, e o mais explorado na expografia. Exu é um orixá associado à fertilidade e à comunicação entre os vivos e os mortos,
19. Freitas e Cunha (2014, p. 192).

20. Ibid., p. 198-199. 
21. Lopes (2008, p. 152).

22. Cf. Sansi-Roca (2007).

23. Apesar de não ser o primeiro museu com coleções afro-brasileiras, consiste em um dos pioneiros que se dedicaram exclusivamente a essa temática e é a primeira instituição museológica com essa nomenclatura. Conforme destacamos anteriormente, somente em 1982 foi criado o Museu Afro-Brasileiro de Salvador, da Universidade Federal da Bahia, organizado por Pierre Verger, e em 2004 o Museu Afro Brasil, em São Paulo, a partir da coleção particular do curador Emanoel Araújo. O Museu Nacional Afro Brasileiro de Cultura e Memória, a ser implantado em Brasília, ainda se encontra em fase de discussão e não possui data prevista para ser implementado. deuses e humanos, e sua principal insígnia é o falo. Crianças, adultos e jovens ficavam espantados com a estátua representando Exu (Chico Tababuia) no museu, pois seu pênis é enorme. Em sintonia com o imaginário ocidental cristão, associavam as representações de Exu ao demônio, ou seja, reproduziam a imagem antropomórfica deste orixá divulgada na Idade Média. No núcleo de religião há várias estátuas e imagens com chifres, rabos e tridentes. Este mesmo núcleo integra ainda imagens e estátuas de santos católicos e das entidades de umbanda, representando as dezenas de entidades que formam as linhas de pretos velhos, caboclos, erês, exus, pombagiras, ciganos, marinheiros, boiadeiros etc., como uma das mais ricas formas de expressão desse imaginário religioso afro-brasileiro. ${ }^{21}$

Das transformações e reelaborações da musealização dos objetos afrorreligiosos no Brasil, também é importante sublinhar nas últimas décadas a criação de memoriais e museus comunitários em terreiros de candomblé e umbanda, práticas que reorientaram as leituras sobre a sacralização e contribuíram para novas problematizações em torno dos procedimentos de preservação manejados comumente no campo dos museus e da Museologia. ${ }^{22}$ Os objetos não são retirados do contexto, muitos continuam, inclusive, sendo mobilizados nos rituais religiosos, gerando uma sobreposição de deslocamentos simbólicos acionados pela musealização.

○ fato é que na literatura sobre os museus afro-brasileiros ainda são escassos os trabalhos que analisam o contexło de criação, a formação da coleção e os deslocamentos afrorreligiosos de algumas instituições, especialmente as localizadas fora das capitais dos estados e dos grandes centros urbanos. Nosso intuito é analisar essas experiências no Museu Afro-Brasileiro de Sergipe, localizado na cidade de Laranjeiras, SE, inaugurado em 1976, uma das primeiras instituições com essa temática no Brasil. ${ }^{23}$

\section{ABRINDO CAMINHOS: PERCURSOS DE UM MUSEU AFRO-BRASILEIRO EM SERGIPE}

As políticas públicas voltadas à defesa e à preservação dos bens de valor cultural no Brasil foram impactadas pela Carta de Brasília, documento oriundo do Encontro dos Governadores organizado pelo então Ministério da Educação e Cultura em 1970. Esse encontro fomentou, dentre outras ações, a criação de legislação específica no âmbito dos estados para a proteção e valorização dos bens naturais e de valor cultural; a criação dos órgãos estaduais de proteção aos acervos; e a ampliação dos recursos financeiros destinados à proteção dos bens nos âmbitos federal, estadual e municipal. No mesmo sentido, contribuiu para a 
implantação de cursos de formação de arquitetos e técnicos especializados na proteção dos bens culturais, especialmente museólogos e arquivistas; para a criação, nos estabelecimentos de ensino de níveis primário, secundário e universitário, de disciplinas visando a difusão do conhecimento e a compreensão dos acervos de valor histórico e artístico existentes no Brasil; e para que as administrações estaduais e municipais criassem museus, bibliotecas e arquivos regionais, em prol da proteção de objetos de valor histórico e artístico. ${ }^{24}$

No ano seguinte e como resultado da Carta de Brasília ocorreu no Museu de Arte Sacra da Universidade Federal da Bahia, em Salvador, o II Encontro dos Governadores, sendo o estado de Sergipe representado pelo Conselho Estadual de Cultura e pelo Departamento de Cultura do Patrimônio Histórico.

Desses dois encontros e das ações articuladas pelo Instituto do Patrimônio Histórico e Artístico Nacional junto aos ministérios do Planejamento e Coordenação Geral, da Educação e Cultura e da Indústria e Comércio do Interior, resultou uma Política Nacional de Cultura que, dentre diversas ações, criou o Programa Integrado de Reconstrução das Cidades Históricas do Nordeste com sua Utilização para Fins Turísticos, posteriormente intitulado de Programa das Cidades Históricas (PCH), além do Programa de Ação Cultural (PAC). O primeiro era voltado à recuperação e/ou criação de infraestrutura ambiental e física e o segundo para a dinâmica do produto cultural brasileiro, ambos destinados a "estimular o desenvolvimento da indústria turística nacional".

Ainda nesse contexto, os ministérios do Planejamento e Coordenação Geral e de Educação e Cultura criaram um Grupo de Trabalho Interministerial para formular, em versão preliminar, o Programa de Reconstrução das Cidades Barrocas do Nordeste, destinado à recuperação de cidades consideradas de relevante interesse histórico e artístico, e a possibilidade dessas cidades, integradas em roteiros turísticos, atraírem investimentos à região Nordeste. $\bigcirc$ resultado do Grupo de Trabalho Interministerial foi entregue em maio de 1973, agregando em três eixos prioritários as localidades que seriam atendidas: 1) dotadas de infraestrutura adequada ao turismo; 2) em vias de desaparecimento pela destruição; e 3) sem infraestrutura adequada, mas em condições não tão precárias quanto às localidades do segundo grupo. ${ }^{25}$

O fato é que entre 1973 e 1979 foram financiados 193 projetos de restauração de monumentos, intervenções em dez conjuntos urbanos, realização de cursos e seminários, além da realização de planos diretores de preservação. Em 1977, o programa foi estendido aos estados de Minas Gerais, Espírito Santo e Rio de Janeiro e, dois anos depois, ampliado para todo o território nacional quando incorporado ao Iphan. ${ }^{26}$ 
27. Cf. Dantas (1988).

28. Ibid., p. 101.

29. Gonçalves (2015, p. 216).

30. Dantas (2015, p. 101).

31. Cf. Azevedo (2013).
Dentre as cidades nordestinas contempladas, Laranieiras, SE, foi enquadrada no grupo de "cidades em vias de desaparecimento". Localizada na região do Cotinguiba, consistiu em um dos principais espaços de produção açucareira do Nordeste no século XIX. A pequena cidade ainda hoje é um dos redutos mais importantes da tradição nagô e local de vigorosa proliferação de diferentes cultos afro-brasileiros e manifestações das culturas populares. ${ }^{27}$

No início da década de 1970, desânimo e ressentimento marcavam a população de Laranjeiras, "alegando-se que as atenções governamentais se concentravam em São Cristóvão, a antiga capital, a Cidade Monumento que se tornara objeto de atenções especiais", somados ao fato de inúmeros bens significativos para a população laranjeirense terem sido transferidos para uma instituição museológica recém-criada nessa localidade: "as melhores peças da antiga Casa de Laranjeiras foram levadas para o Museu Histórico de São Cristóvão". ${ }^{28}$

Na verdade, esse sentimento da população, aliado à transferência de seus objetos considerados representativos para o Museu Histórico de Sergipe e, posteriormente, para o Museu de Arte Sacra, ambos na cidade de São Cristóvão, e o seu enquadramento no Programa de Reconstrução das Cidades Barrocas do Nordeste como "cidade em via de desaparecimento", contribuíram para a construção do que José Reginaldo dos Santos Gonçalves definiu como uma "retórica da perda". Nesses termos, o patrimônio "aparece como um dado individualizado, um objeto que pode ser nitidamente identificado, definido juridicamente e, portanto, preservado, embora sob a perene condição de possível perda de sua forma original ou de sua 'autenticidade'" 29

Visando enfrentar a retórica da perda e valorizar a "autenticidade" do que sobreviveu do passado de Laranjeiras, o jornalista laranjeirense Pedro Paulo Valverde iniciou uma campanha "imbuído do ideário dos governos militares da época, em que patrimônio histórico, folclore e artesanato entravam como componentes de uma política voltada para incrementar o turismo". 30 Esse movimento coincidiu com uma grande efervescência na cidade em decorrência das ações financiadas pelo Programa de Reconstrução das Cidades Barrocas do Nordeste.

Um dos resultados foi a elaboração de um Plano Diretor de Preservação, executado a partir de consulta pública sob a gerência do Grupo de Restauração e Renovação Arquitetônica e Urbana (Grau) da Faculdade de Arquitetura da Universidade Federal da Bahia sob a coordenação do professor Paulo Ormindo David de Azevedo. ${ }^{31}$

Como ação resultante dos I e || Encontro de Governadores (1970/1971) e imbuído por esse conjunto de discursos sobre a perda, o governo de Sergipe tombou em 12 de março de 1971 o "Conjunto arquitetônico, urbanístico e 
paisagístico da cidade de Laranjeiras - construções urbanas de caráter civil, institucional, residencial e religioso dos séculos XVII, XVIII, XIX e XX." 32 Estimulada por essa movimentação, a cidade passa a abrigar novos espaços de cultura e memória. Em 1973, por exemplo, a casa em que nasceu o escritor João Ribeiro é tombada em âmbito estadual ${ }^{33}$ e nela se instala uma instituição cultural em 1974.

Para além da restauração do patrimônio de pedra e cal, houve um somatório de esforços para a valorização das manifestações culturais e a criação de espaços de memória para atender às recomendações do PCH, do PAC e do Programa Integrado de Reconstrução das Cidades Históricas do Nordeste. Para isso, concorreram as contribuições de pensadores sergipanos vinculados à Campanha de Defesa do Folclore Brasileiro (CDFB), sob a liderança e colaboração do pesquisador Bráulio do Nascimento:

Foi nesse contexto que Bráulio se voltou para Sergipe, dando suporte institucional às demandas colocadas por intelectuais e autoridades locais. Em 1976, discutia-se um evento cultural a ser realizado em Laranjeiras. Ele, como diretor da CDFB, veio a Sergipe, onde contava com amigos como Luiz Antônio Barreto e Jackson da Silva Lima, e viabilizou a criação do Encontro Cultural de Laranjeiras, que teve a primeira edição em maio daquele ano. Esse gesto inaugural foi decisivo, sendo repetido e ampliado nos anos subsequentes, de modo que, sempre no mês de janeiro, aconteceram novas edições do Encontro promovidas pelo Governo de Sergipe, pela Prefeitura de Laranjeiras e com apoio de muitas entidades, sendo capitaneado no plano local por Luiz Antônio Barreto. ${ }^{34}$

Concomitantemente, ao pensar e elaborar a proposta do Encontro Cultural, Luiz Antônio Barreto, então assessor da segunda gestão do governo estadual de José Rollemberg Leite, com o apoio do Conselho Estadual de Cultura, presidido na ocasião por Antônio Garcia Filho, se mobilizou para a criação de um museu que evidenciasse aspectos da história sergipana no período da monocultura canavieira e que fosse sediado em Laranjeiras, "lugar de preto mais preto de Sergipe". ${ }^{35}$ Certamente a criação de um museu em torno dessa temática e a escolha de sua sede em uma das cidades do Vale do Cotinguiba marcada por forte herança africana contribuíram para definição de sua especificidade, manifesta no acervo e em sua nomenclatura, Museu-Afro Brasileiro de Sergipe.

Nesses termos, é importante reconhecer essa movimentação tendo em vista os dois Encontros dos Governadores, a Carta de Brasília e o Programa de Reconstrução das Cidades Barrocas do Nordeste que recomendaram a criação de museus estaduais e municipais e de museus regionais. No caso de Laranjeiras, por uma iniciativa do pesquisador Luiz Antônio Barreto, surgiu a ideia de criar um museu na Casa Aquiles Ribeiro, situada na antiga Rua Direita do Comércio,
32. Decreto $\mathrm{n}^{\circ} 2.048$, de 12 de março de 1971 . Inscrição no Livro de Tombo $\mathrm{n}^{\circ} 1$ Geral - fls. 3 e 4 . Cf. Brasil (2005).

33. Decreto 2.726 , de 27 de novembro de 1973. Cf. Brasil (2005).

34. Dantas (2016, p. 1).

35. Cf. Lima (2001) 
36. Andrade (2005, p. 17).

37. Abreu (2008, p. 134).

38. Dantas (2014, p. 38-39). atual Rua José do Prado Franco, $n^{\circ} 70$. O sobrado pertencente ao Desembargador Aquiles Ribeiro, restaurado através de financiamento de políticas públicas e adquirido pela prefeitura municipal, havia funcionado como "casa de comércio e residência ao mesmo tempo quando fora propriedade da família Nogueira de Freitas Brandão, depois ainda [...] como escola, exatoria, biblioteca pública, Museu Horácio Hora e Casa Laranjeiras". 36

Na verdade, a escolha do sobrado colonial para abrigar um acervo museológico sobre o período da monocultura canavieira em Sergipe e a contribuição de Laranjeiras nesse processo prenunciava a ambiguidade que demarcaria sua trajetória. Apesar de um avanço no que diz respeito às práticas museológicas anteriores que difundiam um discurso marcado pela antropologia evolucionista e consideravam os objetos de matriz africana como testemunhos de fetichismo e provas de crime, não foi realizada de modo contundente "uma intervenção social e política na construção de novas mentalidades, na luta contra o preconceito, o racismo e a intolerância". ${ }^{37}$

Os itinerários de formação da coleção museológica merecem ser pensados como partes de um contexto mais amplo, que traduz as políticas públicas em torno das coleções de matriz africana no Brasil e em Sergipe:

No final nos anos 70, a política governamental do Estado interessou-se por acervos das religiões de matriz africana, criando um Museu Afro-brasileiro em Laranjeiras, inclusive adquirindo peças do extinto Museu de Arte e Tradição, o museu particular de José Augusto Garcez; apesar disso, os objetos dos terreiros depositados no IHGSE permaneceram invisíveis e silenciosos. Desconcertante é saber que assim continuaram por toda a década de 80 , quando no plano nacional aprofundava-se o interesse pelo negro e por suas heranças africanas. Um amplo projeto de registro e catalogação dos acervos afro-brasileiros das coleções existentes em museus nordestinos, inclusive em museus de institutos históricos foi desenvolvido por iniciativa do Instituto Nacional de Folclore. Sob a coordenação de museólogo e pesquisador Raul Lody foram catalogadas as coleções afro-brasileiras sob a guarda do Instituto Histórico da Bahia e de Alagoas, além de acervos de museus universitários e outras entidades culturais do Nordeste. Mas, nada foi feito em Sergipe, apesar de Raul Lody ser frequentador habitual do Encontro Cultural de Laranjeiras. ${ }^{38}$

Ao afirmar que a partir dos anos 1970 a política governamental de Sergipe passa a se interessar em "acervos das religiões de matriz africana", é importante pontuar esse "interesse" graças à colaboração de pesquisadores ligados à Comissão Sergipana de Folclore (CSF), ressurgida em 1976, incentivados por Bráulio do Nascimento e contando com o apoio de Luiz Antônio Barreto, Aglaé d'Ávila Fontes, Beatriz Góis Dantas e Agamenon Guimarães Oliveira, entre outros. 
Desde os anos finais da década de 1960 e início de 1970, Luiz Antônio Barreto, na condição de editor do jornal Gazeta de Sergipe, publicava notícias de terreiros: "Serão encerradas hoje as comemorações de inauguração do terreiro (Abaçá) da Yalourixa (sic) Nanã [...] Hoje todo o corpo redacional da 'GS', bem como o pessoal da gerencia, se fará presente ao Abaçá de Nanã, atendendo especial convite enviado". ${ }^{39}$ Da mesma forma, a pesquisadora Aglaé Fontes pesquisava os grupos culturais e a lúdica popular, mas também registrava através de fotografias as festas em terreiros na periferia de Aracaju na companhia de pessoas ligadas à recém-criada Empresa Sergipana de Turismo (Emsetur). A antropóloga Beatriz Góis Dantas pesquisava a Irmandade de Santa Bárbara Virgem, analisando as taieiras e as memórias do culto nagô em Laranjeiras, através da trajetória da sacerdotisa Umbelina Araújo. $\bigcirc$ geógrafo Agamenon Oliveira visitava os antigos sacerdotes das religiões afrobrasileiras em Sergipe para a construção dos primeiros registros sistematizados sobre o nagô, o toré e o candomblé sergipanos.

Todos esses pesquisadores concorreram, cada qual a sua maneira, para a construção de uma "imaginação museal"40 que contribuiu para a efetivação de um museu afro em Sergipe, através de suas pesquisas, muitas das quais publicadas nos Cadernos do Folclore, no Documentário Sonoro do Folclore Brasileiro llançados pela Campanha de Defesa do Folclore Brasileirol e na Revista Sergipana de Folclore (órgão da Comissão Estadual), ou sensibilizando as autoridades locais para a criação dessa instituição. Percebe-se, assim, um trânsito entre o pensamento sobre museus e temáticas afro-brasileiras articuladas pela temática do folclore, além de constantes interlocuções entre as discussões nacionais e estaduais, tendo Bráulio Nascimento como um dos principais mediadores:

Em Sergipe, a CDFB, sob a direção de Bráulio, também apoiou ou patrocinou cursos e jornadas realizadas em convênio com o governo, com a Comissão Sergipana de Folclore ou com a Universidade, na qual chegou a ser criada uma disciplina de folclore em 1976. Promoveu mapeamento das manifestações folclóricas sergipanas, trabalho infelizmente não publicado; possibilitou a qualificação de estudantes em cursos realizados na Fundação Joaquim Nabuco em Recife, de onde retornavam para ocupar espaços nas agências culturais do estado e do município. ${ }^{41}$

Além disso, conforme sublinhou Beatriz Góis Dantas, ${ }^{42}$ o Instituto Nacional de Folclore desenvolveu um projeto de catalogação de acervos afro-brasileiros em museus do Nordeste sob a coordenação do antropólogo e museólogo Raul Lody. Apesar dessas coleções em Sergipe não terem sido catalogadas nesse período, é
39. Gazeta de Sergipe (23 out. 1971, p. 1).

40. Chagas (2009).

41. Dantas (2016, p. 1).

42. Dantas (2014). 
43. Gazeta de Sergipe (1975, p. 6).

44. O Museu Sergipano de Arte e Tradição também possuía uma coleção intitulada de "Etnografia" composta por objetos afrorreligiosos. Todavia, esses objetos não integraram o conjunto inicial adquirido para a formação do Mabs. Cf. Garcez (1958). inegável o trânsito de conhecimentos em torno de sua importância e de um deslocamento do olhar para esses acervos, nos cursos patrocinados pela Campanha em Defesa do Folclore Brasileiro, no Museu do Folclore Edson Carneiro (Rio de Janeiro, RJ), na Fundação Joaquim Nabuco (Recife, PE) e no próprio estado de Sergipe, com a presença desses pesquisadores sergipanos.

fato é que, na concepção de turismo vinculado ao patrimônio edificado de pedra e cal e ao folclore, esse conjunto de ações confluiu no modo como o Museu Afro-Brasileiro de Sergipe começou a ser pensado e na sua importância no campo dos museus brasileiros dedicados à temática afro. Um ano antes da criação do museu, a Gazeta de Sergipe propagava esse ideário coerente com a proposta do Programa Integrado de Reconstrução das Cidades Históricas do Nordeste, destacando a importância da cultura e da religiosidade negra em Laranjeiras:

Passado o Ano Novo, o dia de Reis está pintando com manifestações folclóricas em diversos municípios sergipanos. A EMSETUR promete atuar em Laranjeiras com o DCPH e a UFS homenageando a Bilina, a das Taieiras, recentemente falecida. Será passado em Laranjeiras, um filme com texto de Beatriz Góes (sic) Dantas, em cores, o último documentário sobre a artista laranjeirense. Na oportunidade se apresentarão a Chegança e o São Gonçalo. ${ }^{43}$

O ano de 1976 passa a ser emblemático para Laranjeiras e para as ações culturais que lá foram efetivadas. Em janeiro desse ano foi criado o Museu AfroBrasileiro de Sergipe (Mabs), oficializado no mês seguinte através do Decreto n. ${ }^{\circ}$ 3.339. Inicialmente ficou sob a responsabilidade de Ana Conceição Sobral de Carvalho obter acervos para a sua formação, pensar sua primeira exposição e abri-lo ao público. Tão logo assumiu a gestão do museu, fora substituída por Telma Santos e esta, por Telma Rosita.

Após a obtenção dos objetos que constituíram o acervo inaugural do museu, foram adquiridas peças do extinto Museu Sergipano de Arte e Tradição, instituição particular criada e mantida em Aracaju por José Augusto Garcez, especialmente das coleções por ele nomeadas como "arte popular em geral, inclusive artesanato", "instrumentos de tortura" e "ciclo da escravidão: peças e documentos". ${ }^{44}$ Posteriormente, a Paróquia de Malhador, SE, doou um conjunto de peças relacionadas ao universo dos engenhos da região, com destaque para instrumentos de escravização e para a temática da produção laboral dos escravizados e seus descendentes.

Todavia, convém registrar as transformações no discurso museológico visto que, até este momento, as coleções afrorreligiosas não possuíam centralidade na 
exposição. Ao analisar as memórias do primeiro servidor do Mabs, Amintas Vieira Souza, Jislaine dos Santos descreve o acervo do museu e sua exposição inaugural: "eram apresentados berimbaus, artesanatos, que eram expostos na parte inferior. Eram objetos de palha, abano, esteira, peneira etc.", reconhecendo uma mudança nessa leitura a partir da gestão de Telma Rosita, quando "os berimbaus e os artesanatos saem de cena". ${ }^{45}$ Nesse aspecto, compete observar que houve uma mudança de foco no discurso expositivo, momento em que a ideia de "artesanato afro-brasileiro" ganhava evidência no campo do folclore nacional, especialmente reconhecendo a importância da cultura material afrorreligiosa.

É sintomático, por exemplo, que em 12 de maio de 1977, um ano após a criação do Mabs, tenha sido inaugurada a exposição "Artesanato Religioso Afro-Brasileiro" e lançado o Caderno de Folclore sobre pano da costa, de autoria de Raul Lody. ${ }^{46}$ A exposição foi promovida pela Campanha de Defesa do Folclore Brasileiro, na Fundação Nacional de Arte, Rio de Janeiro, com peças do acervo do Museu do Folclore e da coleção particular de Raul Lody. No mesmo ano, a exposição consistiv em uma das atrações da inauguração da nova sede do Museu Théo Brandão de Antropologia e Folclore da Universidade Federal de Alagoas, em Maceió, AL. Desse modo, além do trânsito de informações promovido pela CDFB e o papel dos museus nesse processo, a leitura dessas peças como artesanato estimulada pelo movimento folclórico não pode ser desprezada:

O grande destaque são os dez orixás representados em manequins, portando os trajes rituais de Exu, Ogum, Oxóssi, Omolu, Ossãe, Oxum, Xangô, lansã, Yemaniá e Oxalufan, acompanhados dos ornamentos simbólicos. Há coleção de panos da Costa, da África e do Brasil, esculturas e símbolos religiosos em metal, madeira e argila, e ainda estatuetas em marfim representativas dos mitos angolanos. São focalizados também adereços, fios de contas e demais símbolos utilizados nas indumentárias rituais. ${ }^{47}$

Isso é significativo quando percebemos uma mudança no discurso do Mabs no final da década de 1970. Impactado por essas transformações no campo do folclore nacional, especialmente em torno do tratamento da cultura material afrorreligiosa, o museu aos poucos ampliou seu acervo inserindo um conjunto representativo de objetos do universo religioso afro-brasileiro. Os efeitos dessa mudança contribuíram de forma exemplar para reconhecermos o museu como "zona de contato" nos moldes apresentados por James Clifford, ${ }^{48}$ visto que consiste em um lugar de troca, negociação e conflito. As transformações na exposição do Mabs com o protagonismo do discurso afrorreligioso, como veremos a seguir, contribuiu para a eclosão de "zonas de contacto locais/globais, sítios de criação
45. Santos (2016, p. 60).

46. Jornal dos Sports (29 maio 1977, p. 6).

47. Ibid.

48. Cf. Clifford (2003). 
49. Ibid., p. 251.

50. Cf. Aguiar (2008).

51. Cf. Andrade (2005).

52. Dantas (2014, p. 136). de identidade e de transculturação, de contenção e de excesso [...] exemplos perfeitos do futuro ambíguo da diferença cultural" ${ }^{49}$

\section{AS ITINERÂNCIAS DE EXU NA EXPOSIÇÃO MUSEOLÓGICA}

Várias vezes, em ocasiões públicas na cidade de Laranjeiras, de forma bem eloquente diante do público que o cercava, Luiz Antônio Barreto afirmou categoricamente: "comprei um terreiro fechado para montar um museu". A assertiva do pesquisador, quando evocava suas memórias sobre a obtenção da coleção afrorreligiosa do Mabs, lembra um provérbio iorubano que diz: Kan àláilare kereké fifunni kiose mo yiyató! (Um simples ato pode fazer muita diferença!).

A diferença apresentada no seu discurso de aquisição e montagem de um museu insere no debate da própria formação do Mabs uma reflexão sobre sacralização e dessacralização. Dito isso, é possível compreender um exagero quando o pesquisador se referia à compra de "um terreiro fechado". Na verdade, os objetos adquiridos não constituíam a totalidade dos bens tangíveis utilizados nas liturgias e ritos de um terreiro, mas algumas peças que, pela primeira vez, podiam ser vistas em uma exposição museológica sergipana sem terem sido resultantes da ação truculenta da polícia na primeira metade do século XX.50

As peças foram adquiridas do Centro de Obras Sociais São Sebastião, Oxóssi Tawamin, do babalorixá Gilberto da Silva, popularmente conhecido como Lê. Oriundas de um terreiro de candomblé localizado em Aracaju, consistiam em um tridente de ferro (insígnia de Exu), fios de contas, ferramentas de orixás, braceletes, adjás, capanga de palha, ferros de orixás, quartinhas e talhas de louça, palmatória, oxês de metal, um punhal, um trono, um conjunto de atabaques (rum, rumpi e lé), chifres, assentamentos de orixás em louça, idés, braceletes e couraças de metal. ${ }^{51}$

Ao adquirir essas peças para compor o acervo do Mabs, Luiz Antônio Barreto, ainda que na intenção de vislumbrar o campo religioso com uma dimensão folclórica, inseriu elementos até então incomuns na experiência dos museus sergipanos. Exceção a esse fato, conforme destacamos, é o acervo afro-religioso, espólio das investiduras da polícia aos terreiros de Aracaju na década de 1940, sob a guarda do Museu Galdino Bicho, do Instituto Histórico e Geográfico de Sergipe, coleção "sem nome, sem registros, sem lembranças". ${ }^{52}$ 
$\bigcirc$ fato é que, ao afirmar ter comprado "um terreiro fechado para montar um museu", o pesquisador expressou a sua intenção de vocacionar o próprio museu para além da concepção de reverberar a escravidão e da negação de luta por liberdade dos escravizados e dos seus descendentes. Opôs-se aos discursos da não resistência dos africanos e de suas gerações nascidas pós diáspora.

Ao longo das três primeiras gestões do Mabs, a ideia de um museu criado para expor aspectos significativos da história de Sergipe no período da monocultura canavieira foi a prioridade institucional. Com a aquisição da coleção do Centro de Obras Sociais São Sebastião, Oxóssi Tawamin, as ferramentas de orixás e os fios de contas passaram a integrar a exposição de longa duração. Todavia, a maioria dos objetos, incluindo o tridente de Exu, ficou esquecida na reserva técnica.

Com o advento do centenário da Abolição da Escravidão no Brasil, quando o país construiu uma agenda de celebrações e reflexões, o Mabs teve uma nova gestora, Izaura Júlia de Oliveira Ramos, que reconstruiu a exposição museológica. Adotou como eixo condutor da ocupação dos espaços do sobrado o conceito da cosmogonia iorubana de orun-aiyé lencontro dos mundos espiritual e físico). Desse modo, propôs ao público visitante a visão de dois mundos distintos, ocupando o espaço do museu, um sobreposto ao outro e separados por uma escada que conduziria o visitante para o andar superior e/ou ao plano inferior.

A estratégia utilizada pela nova gestora redimensionou a proposta original da exposição e priorizou a retomada vocacional do museu defendida por Luiz Antônio Barreto. Para tanto, retirou da reserva técnica as peças afrorreligiosas adquiridas a partir da compra "do terreiro fechado" e, visando justificar a inclusão dos orixás em exposição, além de defender uma lógica na composição e disposição do acervo, se sustentou no mito da criação iorubano:

Quando Òrisà N'lá (O Grande Òrisà) - um dos títulos de Obátálá - pegou suas instruções a fim de fazer o que havia sido determinado por Olódùmarè, ele passou por Ėsù, que the perguntou se havia feito as oferendas necessárias para a realização do trabalho, Òrìà N'lá não the deu importância. Em razão disso, durante a sua caminhada, ele ficou bastante sedento e bebeu abundantemente de uma bebida extraída de uma palmeira - emu. Em consequência, ficou sem forças e sem condições de prosseguir para executar a sua tarefa, caindo em sono profundo. Olódùmarè enviou Odùduwà para verificar o que estava acontecendo. Ao ver Òrisà N'lá adormecido, pegou os elementos da criação e foi comunicar o ocorrido a Olódùmarè, que, diante do fato, determinou que ele, Odùduwà, fosse criar a Terra. Após a tarefa cumprida, eis que Òrìsà N'lá despertou, e, ao tomar ciência do que havia acontecido, foi até Olódùmarè reivindicar os seus direitos, o que the foi negado. A partir daí, ficou proibido de beber emu e de usar o azeite-de-dendê. Porém, foi the dada à tarefa de modelar o barro para a criação do ser humano. Mais tarde, ouve o reencontro de 
53. Beniste (2003, p. 54)

54. Cf. Herbele (2015).

55. Ibid., p. 54

56. Ibid., p. 55
Òrisà N'lá e Odùduwà, com discussões e disputas entre os dois, até que se deu a intervenção de Òrúnmilà para trazer a paz entre ambos..$^{53}$

Assim como na narrativa iorubana, a exposição museológica apresentava os conflitos e as tensões entre expor o mundo do eito, do sofrimento dos escravizados na produção canavieira, e a sua oposição, demonstrando a resistência a partir do religioso. Para tanto, trouxe à cena o tridente de Exu conduzindo os demais orixás a partir dos acervos do museu. Com seu caráter "irascível, provocador e polêmico", ao ser inserido em exposição ainda que de forma discreta, sem grande visibilidade em face da quantidade de elementos e insígnias dos demais orixás, Exu não deixou de criar situações embaraçosas, conforme relataram alguns dos ex-funcionários do museu e adeptos das religiões afro-brasileiras em Laranjeiras. Todavia, o momento de celebração do Centenário da Abolição permitia a ousadia de retirá-lo do anonimato e, de certo modo, blindava a gestora de possíveis críticas. Em seu discurso, Exu estava ali representado não como um elemento sagrado, mas como uma representação cultural.

Apesar desse discurso, aos poucos surgiram alguns episódios de controvérsia envolvendo a exposição desses objetos nos moldes apresentados por Fernanda Herbele, ${ }^{54}$ quando investigou os deslocamentos de elementos de referência afrorreligiosa de um terreiro para um museu, delineando os bastidores da produção de "sagrados" em contextos e instituições seculares. Nesses termos, compreende que esses casos demonstram a "importância da categoria 'patrimônio' na interação entre religiões afro e Estado, evidenciado a centralidade que a associação com a ideia de 'cultura' assume no reconhecimento da presença do afrorreligioso no espaço público". 55

Assim como ocorreu com os deslocamentos do tridente de Exu no Mabs, em que alguns visitantes e moradores o evidenciavam como objeto sagrado em virtude da procedência de um terreiro e em virtude da própria demonização que as religiões afro sofrem, esses conflitos atentam "para o paradoxo configurado pela convivência entre o sagrado religioso e o sagrado encarnado pelo patrimônio público no âmbito da instituição museal". ${ }^{56}$ Além disso, a inserção da temática afrorreligiosa na exposição do Mabs se justificou no mito do orun-aiyé que, por sua vez, reforçava uma leitura sacralizante:

Em épocas remotas, o Àiyé e o Òrun não estavam separados. A existência não se desdobrava em dois níveis e os seres dos dois espaços iam de um a outro sem problemas; os Òrisà habitavam o Àiyé e os seres humanos podiam ir ao Òrun e voltar. Foi depois da violação de uma interdição que o Òrun se separou do Àiyé e que a existência se desdobrou; os seres humanos não têm mais a possibilidade de ir ao Òrun e voltar de lá vivos [...] 
no tempo em que o Òrun limitava diretamente com o Àiyé, um ser humano tocou indevidamente o Òrun com mãos sujas, o que provocou a irritação de Olórun, entidade suprema. Este soprou, interpondo seu òfurufú ar divino (hálito) que, transformando-se em atmosfera, constituiu o sánmò ou céu. ${ }^{57}$
57. Santos (1984, p. 54).

58. Ramos, 12 abr. 2001.

59. Cf. Assunção (2010).

Dessa forma, no plano inferior do sobrado, encontravam-se as salas de Economia Açucareira, de Instrumento de Tortura, de Senhoril e, anos depois, foi criado um espaço que representava a cozinha da Casa-Grande. Já no andar superior, a sala das religiões afro-brasileiras que, ao longo dos anos da gestão de Izaura Júlia, foi crescendo de maneira significativa, ao ponto dessa gestora transformar todo o piso superior em um espaço de evocação das religiões afrobrasileiras em Sergipe.

Evitando as críticas que destacavam o fato de não haver representatividade das manifestações afrorreligiosas de Laranjeiras, mas sim do candomblé de Aracaju, a gestora se mobilizou e conseguiu através de compra e doações obter objetos do Terreiro Filhos de Obá e algumas poucas peças do Nagô de Herculano e Bilina, ambos de Laranjeiras, além de inserir um peji que mesclava santos católicos e peças de candomblé.

Em meio a essa reformulação, Izaura Júlia adquiriu manequins de cor preta e os vestiu ritualisticamente sob a orientação do babalorixá Jorge dos Santos, conhecido como Pai Jorginho, que também trabalhava no museu. Retirou das vitrines e da reserva técnica parte do "terreiro fechado" que outrora fora comprado para montar o museu, surgindo, assim, a Sala dos Orixás. No final de sua gestão, também expôs imagens de gesso de Exus e Pombajiras da umbanda, o que propiciou recusas e críticas por parte de alguns, medo e receio por parte de outros.

Após muitas críticas e algumas recusas de visitação às instalações do Mabs, a gestora resolveu recolher na reserva técnica as imagens de gesso de Exu e Pombajira. Todavia, não retirou Exu da exposição e criou uma sala específica. A ideia, segundo Izaura Júlia, "era dar um tratamento especial a Exu. Era restituir, a partir da sua inserção na exposição, à condição original de um deus mensageiro, intermediador entre Deus e os homens". Para isso, prossegue ela, "era preciso representá-lo como no Candomblé". 58

Embora a gestora tivesse a intenção de representar Exu, como no candomblé, o que se viu foi um Exu sob forma de "Catiço", na umbanda, ${ }^{59}$ acompanhado por um manequim representando a Pombajira. O circuito expositivo fazia com que os visitantes só tivessem acesso às demais salas do piso superior visitando primeiramente a Sala dos Exus. 
60. Cf. Gonçalves (2007).

61. Ibid., p. 217.

62. Os trechos de depoimentos apresentados neste texto consistem em anotações do diário de campo de pesquisador (autoria removida). A pedido dos informantes seus nomes foram suprimidos.

63. Cf. Santos (2016).
Essa situação contribuiu para que ocorresse no Mabs aquilo que José Reginaldo Santos Gonçalves ${ }^{60}$ sublinhou como excesso de ressonância. Se os objetos precisam ter ressonância junto ao público, às vezes a relação instituída pela musealização, no caso de objetos religiosos, extrapola as intenções do projeto curatorial. Esse é o caso exemplar destacado pelo antropólogo ao narrar a experiência do Museu da Polícia Militar no Rio de Janeiro, cujo acervo continha objetos apreendidos em ações políticas de repressão às casas de umbanda:

\footnotetext{
Essa coleção de imagens estava organizada na forma como ela existe num terreiro de umbanda. Entre as imagens estava um exu, feito com a terra de todos os cemitérios da cidade e considerado uma entidade muito poderosa. A razão dessa disposição estava no fato de que o responsável pelo museu, que não era museólogo, mas um velho policial aposentado e, além disso, umbandista, cuidou a seu modo da exposição. Entre as visitas que o museu recebia cotidianamente estavam muitos fiéis da umbanda que iam buscar apoio junto a essas entidades para resolver suas aflições. Poderíamos dizer que, nesse caso, temos um excesso de ressonância: um museu dedicado ao passado e à identidade de uma organização policial aproxima-se da condição de um terreiro de umbanda. Trata-se evidentemente de um caso extremo e, por isso mesmo, bom para expor a dimensão de ambigüidade que parece caracterizar os objetos no contexto dos museus. ${ }^{61}$
}

Apesar de não ter sido essa a intenção, o excesso de ressonância também consiste em característica marcante na Sala dos Exus do Mabs, percebido na relação de alguns funcionários, estagiários, visitantes e moradores de Laranjeiras. ${ }^{62}$ Em conversas com uma das funcionárias, ela informou que "era comum as pessoas pedirem agô antes de entrar na sala, passarem mal. Desmaiar só vi uma vez. Algumas pessoas deixavam moedas". Um dos estagiários também destacou que "passavam mal cotidianamente, teve uma menina que caiu na minha frente quando entrou na Sala de Exu. Até vela já acenderam para ele, um dos monitores deixou vela, cachaça e azeite para ele". Continuou seu relato informando que muitos turistas "saudavam, deitavam, batiam paó, principalmente no Encontro Cultural de Laranjeiras".

Após 19 anos ininterruptos na função de gestora do Mabs, Izaura Júlia foi substituída por Helena Gonçalves que manteve a exposição de longa duração e incentivou a realização de exposições de curta duração com ações educativas que, em sua maioria, reforçavam a temática afrorreligiosa e, por sua vez, o excesso de ressonância. ${ }^{63}$

O fato é que mudanças na Coordenação Estadual de Museus contribuíram para que, no início de 2014, as imagens de Exu e Pombajira fossem retiradas da 
exposição, apesar da resistência de alguns funcionários, estagiários e de parte da comunidade afrorreligiosa laranieirense.

Isso é revelado nas memórias de uma funcionária do museu quando reconheceu, inclusive, que, após a retirada das imagens, se sentiu mal: "comecei a passar mal, com forte dor no peito [...] As responsáveis pela coordenação de museus que realizavam a mudança disseram que iriam modificar porque ali não era um terreiro". Informou ainda que, após o ocorrido, frequentemente aconteciam fatos inusitados no museu: "aparecia um homem negro olhando para mim, quando olhava novamente ele sumia [...] No mesmo local da escada, quando eu passava vinha um vulto, como se quisesse me abraçar". Um dos estagiários que presenciou a retirada das imagens relatou como motivos o desconhecimento do papel de Exu no universo afrorreligioso e a sua demonização por parte de alguns visitantes e de algumas pessoas do campo dos museus em Sergipe: "me chamaram para ajudar a retirar as peças, mas eu me neguei a auxiliar por não concordar. Neguei pelo fato de Exu nunca ter sido ali representado como algo diabólico, mas como um mensageiro, o responsável pela comunicação".

A mudança na exposição museológica acionou o imaginário local, provocando a indignação e a mobilização de lideranças afrorreligiosas, adeptos, pesquisadores e estudantes: "os praticantes começaram a ir no museu atestar a ausência de Exu e exigir seu retorno". A população começou a creditar a responsabilidade da retirada de Exu à desordem que se instalou na cidade no primeiro semestre de 2014. Uma série de ações violentas e criminosas atemorizou a população de Laranieiras, diversos assassinatos ocorreram e o próprio museu foi invadido. Em virtude do caos instalado na cidade, um grupo de babalorixás e ialorixás capitaneado pelo babalaxé Fernando Aguiar realizou um movimento que culminou na elaboração de uma nota de repúdio que em 9 de junho de 2014 viralizou nas redes sociais:

Desde o último Encontro Cultural de Laranjeiras, em Janeiro passado, que a sala dedicada a Ėsù fora desmontada e os acervos que compunham parte da expografia foram lançados à reserva técnica. Certamente uma atitude de alguém no mínimo preconceituosa ou despreparada para trabalhar com conteúdos que exigem saberes, conhecimentos muitos específicos, uma vez que não existe nada no universo mágico religioso afro diaspórico brasileiro que desassociem as divindades do panteão yorubano da figura de Ėsù. Ele é sempre o primeiro, o movimento, a contradição, a ordem/desordem/o equilíbrio/o caos Sem Ele não se tem caminhos, sem ele não se faz nada. Não quero aqui fazer proselitismo nem muito menos creditar ao espaço museal um caráter sacro. Longe de mim, estas proposituras, mas como também pesquisador penso ser uma danação da norma e da ordem, excluir sem nenhum critério justificável ou plausível para a retirada de Ėsù do conjunto dos demais 
Òrìà, cujo o todo fragmentado passa a não ter sentido nenhum. Lembro a vocês que as lógicas judaicas cristãs ocidentais não dão conta de um conjunto dispare e dessemelhante de sentidos, sentimentos e significados das visões de mundo empreendidas pelos africanos e seus descendentes na diáspora. Retirar Ėsù do conjunto das divindades ali em exposição permanente é tão ofensivo ao saber dos valores civilizatórios africanos como retirar a cabeça de um corpo. - penso que qualquer principiante dos estudos afro brasileiros sabe muito disto que acabo de falar- menos a cabeça não pensante que o retirou de lá. Lembro a esta pessoa descompreendida e descomprometida com o saber que sem Ėsù não se faz nada. Há inclusive um velho ditado yorubano que diz: 'Exu matou um pássaro ontem, com uma pedra que jogou hoje para amanhã.'

Nos vários Orikis (Os Oríki - do yorùbá, orí = cabeça, kì = saudar - são versos, frases ou poemas que são formados para saudar o orixá referindo-se a sua origem, suas qualidades e sua ancestralidade.) e Adurás (reza, prece ou oração) a personalidade de Ėsù nos orienta no sentido de respeitá-lo e cultua-lo como forma de evitar o caos, a desordem, o medo, a violência, o terror e o pânico. Exemplos destas situações são diuturnamente entoados nas casas de asé. [...] Diante da desordem e desrespeito para com os saberes ancestrais tradicionais do povo de asé e em respeito as formas tradicionais de conhecimentos dos yorubanos e seus descendentes culturais no Brasil e em Sergipe, queremos o retorno de Ėsù à expografia do Museu Afro-Brasileiro de Sergipe. Temos grandes doutores estudiosos da temática na museologia no CampusLar que poderiam muito bem ser escutados bem como as comunidades tradicionais de terreiro existentes em Laranjeiras. Queremos Ėsù de volta ao lugar que sempre foi dele no Museu. Laaróyè Èsù! Ago mojuba!64

A repercussão imediata do manifesto entre a comunidade de terreiro e pesquisadores do campo da Antropologia e da Museologia contribuiu para que a escultura de Exu voltasse para a exposição de longa duração do Mabs, passando a ocupar a escada, um entrelugar significativo na cosmogonia iorubana a intercambiar os mundos orun-aiyé representados no museu. A retirada e o regresso das imagens de Exu contribuíram para reforçar a sua dupla sacralização enquanto bem do universo religioso e "patrimônio público", acionando um imaginário presente entre os moradores da região e sobre qual campo dos museus e da Museologia foi convocado a se posicionar.

Segundo afirmaram alguns sacerdotes e sacerdotisas do candomblé, em relatos informais e em mobilizações decorrentes do fato, a própria entidade manifestou por meio dos búzios o desejo de permanecer na exposição e informou que o caos gerado na cidade se deveu em grande parte a sua retirada desrespeitosa do museu. A comunidade afrorreligiosa ainda aguarda a realização de um ato de desagravo, com um grande cortejo pelas ruas da cidade e a fixação de uma escultura de Exu na parte interna do Mabs. Essa, segundo acreditam, é a vontade do orixá.

A partir desse fato, podemos fazer coro com o entendimento de Izabela Tamaso quando avaliou os conflitos constitutivos do campo do patrimônio e 
reconhecer o modo como essa tensão ocasionada pela retirada de Exu evidenciou os usos plurais da categoria "patrimônio" e contribuiu para a formação de uma "consciência patrimonial": "visa chamar atenção para a necessária e importante abordagem que atente para as representações e apropriações que os moradores de espaços patrimonializados têm (e fazem) de seus lugares". ${ }^{65}$

Na verdade, o episódio da retirada de Exu do Mabs, ao propiciar que os moradores de Laranjeiras tivessem sua "segurança ontológica" ameaçada, ${ }^{\circ 6}$ contribuiu para que pela primeira vez desde sua criação o museu estimulasse a visualização daquilo que Regina Abreu delineou como uma Antropologia e um museu nativos como estratégias de movimentos sociais. ${ }^{67}$ A tensão originária da retirada de Exu reverberou no campo do patrimônio e dos museus e fez com que a comunidade deliberasse sobre os usos de seus bens representativos e problematizasse as políticas de autorrepresentação por meio da musealização. Essa situação afetou permanentemente os agentes na intermediação deste e de outros mundos, no diálogo entre o que deve ou não ser exposto e a forma dessa exposição, acionando uma multiplicidade de tensões, de identidades e subjetividades, assim como múltipla é a figura de Exu. 


\section{REFERÊNCIAS}

Fontes impressas

COMPROMISSO de Brasília. I. ${ }^{\circ}$ Encontro dos Governadores de Estado, Secretários Estaduais da Área Cultural, Prefeitos de Municípios Interessados, Presidentes e Representações de Instituições Culturais. Brasília, abril de 1970.

Gazeta de Sergipe, Aracaju, 1975, p. 6. Acervo do Instituto Histórico e Geográfico de Sergipe, Aracaju.

Jornal dos Sports, Rio de Janeiro, 29 maio 1977, p. 6. Acervo da Biblioteca Nacional, Rio de Janeiro.

NOVO Terreiro de Nanã será inaugurado hoje. Gazeta de Sergipe, Aracaju, 23 out. 1971, p. 1. Acervo do Instituto Histórico e Geográfico de Sergipe, Aracaju.

Livros, artigos e teses

ABREU, Regina. Tal Antropologia, qual museu? Revista do Museu de Arqueologia e Etnologia, São Paulo, Suplemento 7, p. 121-143, 2008.

AGUIAR, Janaína Couvo Teixeira Maia de. Brincadeiras de Santo: uma contribuição à história dos antigos cultos afro-brasileiros em Aracaju-SE (1920-1960). 2008. Trabalho de Conclusão de Curso (Bacharelado em História), Universidade Federal de Sergipe, São Cristóvão, 2008.

ANDRADE, Créscia Cristina Dantas de. Catálogo de peças do Museu Afro-Brasileiro de Sergipe. 2005. Trabalho de Conclusão de Curso (Licenciatura em História), Universidade Federal de Sergipe, São Cristóvão, 2005.

ASSUNÇÃO, Luiz. A transgressão no religioso: Exus e mestres nos rituais da Umbanda. Horizontes Antropológicos, Porto Alegre, v. 21, n. 1, 2010.

AZEVEDO, Paulo Ormindo David de. Renato Soeiro e a institucionalização do setor cultural no Brasil. In: AZEVEDO, Paulo Ormindo David de; CORRÊA. Elyane Lins (Orgs.). Estado e Sociedade na Preservação do Patrimônio. Salvador: EDUFBA; IAB-BA, 2013. 
BENISTE, José. Òrun-Àiyé: o encontro de dois mundos: sistema de relacionamento nagô-yorubá entre o céu e a terra. $5^{\text {a }}$ ed. Rio de Janeiro: Bertrand Brasil, 2003.

BRASIL/IPHAN. Anais do II Encontro de Governadores para Preservação do Patrimônio Histórico, Artístico, Arqueológico e Natural do Brasil. Salvador, Bahia, de 23 a 29 de outubro de 1971.

BRASIL. Sítios Históricos e Conjuntos Urbanos de Monumentos Nacionais. Volume 1 - Norte, Nordeste e Centro-Oeste. Cadernos Técnicos do Programa Monumenta Brasília: Ministério da Cultura, 2005.

BRULON, Bruno. Passagens da Museologia: a musealização como caminho. Museologia e Patrimônio, Rio de Janeiro, v. 11, n. 2, 2018.

CHAGAS, Mario. A imaginação museal: Museu, memória e poder em Gustavo Barroso, Gilberto Freyre e Darcy Ribeiro. Rio de Janeiro: MinC/IBRAM, 2009.

CLIFFORD, James. Museus como Zonas de Contacto. In: GREEN, R. (Org.). Negociações na Zona de Contacto. Lisboa: Assírio \& Alvim, 2003.

CORRÊA, Alexandre Fernandes. Museu Mefistofélico: a Coleção Museu de Magia Negra do Rio de Janeiro e o significado cultural do primeiro tombamento etnográfico do Brasil, em 1938. Ensaio de Pós-Doutorado. Rio de Janeiro, Universidade Federal do Rio de Janeiro, 2006.

CORREA, Sandra Magalhães. O Programa de Cidades Históricas: por uma política integrada de preservação do patrimônio cultural urbano. Anais do Museu Paulista: História e Cultura Material, n. 24, p. 15-58, 2016.

CUNHA, Marcelo Nascimento Bernardo da. Teatro de memórias, palco de esquecimentos: culturas africanas e das diásporas negras em exposições. 2006. Tese (Doutorado em História), Pontifícia Universidade Católica de São Paulo. São Paulo, 2006.

DANTAS, Beatriz Góis. Bráulio Nascimento, presença em Sergipe. Instituto Histórico e Geográfico de Sergipe, Aracaju, 30 set. 2016. Disponível em: <https://bit.ly/2nJnEH8>. Acesso em 15 jan. 2018.

DANTAS, Beatriz Góis. O Encontro Cultural de Laranjeiras segundo uma observadora participante. Revista Geonordeste, São Cristóvão, SE, n. 2, p. 100-114, ago./dez. 2015.

DANTAS, Beatriz Góis. Tambores silenciosos: a saga dos objetos de terreiros no acervo do IHGSE. Revista do Instituto Histórico e Geográfico de Sergipe, Aracaju, n. 44, p. 21-50, 2014. 
DANTAS. Beatriz Góis. Vovó nagô e papai branco: usos e abusos da África no Brasil. Rio de Janeiro: Graal, 1988.

DOUGLAS, Mary. Pureza e perigo. São Paulo: Perspectiva, 2010.

FREITAS, Joseania Miranda; CUNHA, Marcelo Nascimento Bernardo da. Reflexões sobre a exposição temporária do MAFRO-UFBA - Exu: outras faces. Museologia e Patrimônio, Rio de Janeiro, v. 4, n. 1, 2014.

GARCEZ, José Augusto. Realidade e destino dos museus. Aracaju: Livraria Regina, 1958.

GIDDENS, Anthony. A constituição da sociedade. São Paulo: Martins Fontes, 1989.

GONÇALVES, José Reginaldo Santos. O mal-estar no patrimônio: identidade, tempo e destruição. Estudos Históricos, Rio de Janeiro, v. 28, n. 55, p. 211-228, jan-jun. 2015.

GONÇALVES, José Reginaldo Santos. Antropologia dos objetos: coleções, museus e patrimônios. Rio de Janeiro: Departamento de Museus e Centros Culturais, 2007.

HERBELE, Fernanda. Entre a imagem afrorreligiosa e monumento público: reflexões sobre sagrado e modernidade. In: TAVARES, F.; GIUMBELLI, E. (Orgs.). Religiões e temas de pesquisa contemporâneos: diálogos antropológicos. Salvador: EDUFBA; ABA, 2015.

LIMA Maria Batista. Mussuca - Laranjeiras, lugar de preto mais preto: cultura e educação nos territórios de predominância afrodescendente sergipanos. 2001. Dissertação (Mestrado em Educação), Universidade Estadual do Rio de Janeiro. Rio de Janeiro, 2001.

LOPES, Maria Aparecida de Oliveira. Museu Afro Brasil: ampliando e preservando os bens materiais e imateriais da cultura afro-brasileira. Patrimônio e Memória, Assis-SP, v. 4, n. 1, 2008.

MAGNANI, José Guilherme Cantor. Etnografia como prática e experiência. Horizontes Antropológicos, Porto Alegre, v. 15, n. 32, p. 129-156, 2009.

PRANDI, Reginaldo. Exu, de mensageiro a diabo: sincretismo católico e demonização do orixá Exu. Revista USP, São Paulo, n. 50, p. 46-63, jun.-ago. 2001

SANDES, Juipurema A. Sarraf. O Museu Afro-Brasileiro da Universidade Federal da Babia e sua coleção de cultura material religiosa afro-brasileira. 2010. Dissertação (Mestrado em Estudos Étnicos e Africanos), Universidade Federal da Bahia. Salvador, 2010. 
SANSI-ROCA, Roger. De armas do fetichismo a patrimônio cultural: as transformações do valor museográfico do Candomblé em Salvador da Bahia no século XX. In: ABREU, Regina; CHAGAS, Mario de Souza; SANTOS, Myrian Sepúlveda dos (Orgs.). Museus, coleções e patrimônios: narrativas polifônicas. Rio de Janeiro: Garamond/IPHAN, 2007.

SANT'ANNA, Márcia. Da cidade-monumento à cidade documento: a norma de preservação de áreas urbanas no Brasil. Salvador: IPHAN/Oiti Editora, 2015.

SANTOS, Jislaine dos. A casa antiga que depende do negro e de sua história: Amintas Vieira Souza como "guardião da memória" do Museu Afro-Brasileiro de Sergipe. 2016. Trabalho de Conclusão de Curso (Bacharelado em Museologia), Universidade Federal de Sergipe, Laranjeiras, 2016.

SANTOS, Juana Elbein dos. Os Nàgô e a Morte: Pàde, Àsèsè e o culto Ègun na Bahia. $3^{\mathrm{a}}$ ed. Petrópolis: Vozes, 1984.

SILVA, Vagner Gonçalves da. Exu do Brasil - Tropos de uma identidade afro-brasileira nos trópicos. Revista de Antropologia, São Paulo, v. 55, n. 2, jul. 2013.

TAMASO, Izabela. Em nome do patrimônio: representações e apropriações da cultura na cidade de Goiás. 2007. Tese (Doutorado em Antropologia), Universidade de Brasília. Brasília, 2007.

Site

AGUIAR, Fernando José Ferreira. Perguntar não ofende: cadê o Esu do Museu Afro-Brasileiro de Sergipe, em Laranjeiras?. Disponível em: <https://bit.ly/2oeeNNN>. Acesso em: 3 out. 2019.

Entrevista

RAMOS, Izaura Júlia de Oliveira. [Entrevista cedida, s. n.]. [s. l.], 12 abr. 2001.

Artigo apresentado em 3/12/2018. Aprovado em 18/6/2019.

\section{(cc) BY}

All the contents of this journal, except where otherwise noted, is licensed under a Creative Commons Attribution License 